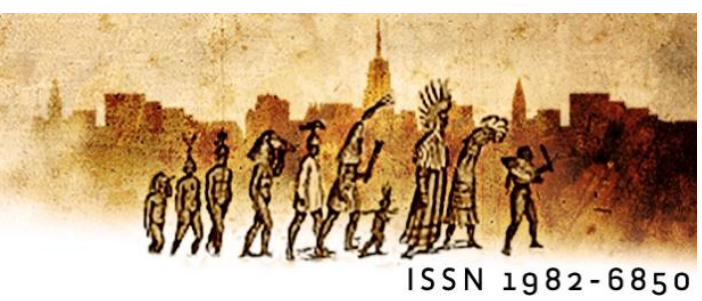

\title{
A visão da história americana em $O$ arco-íris da gravidade, de Thomas Pynchon
}

\author{
Pedro Dolabela Chagasi (UFPR/CNPq)
}

\begin{abstract}
Resumo:
Apresentação panorâmica da ficcionalização da história americana em $O$ arco-íris da gravidade, de Thomas Pynchon. Três referências temporais são empregadas na análise: o período entre 1620 e 1776, fundação do ideário político e religioso que determinaria a autoimagem do país; 1945, momento de glorificação daquela autoimagem; 1973, ano de publicação da obra de Pynchon. Enquanto as duas primeiras datações abrangem elementos ficcionalizados no enredo, a última cobre o momento em que os EUA eram colocados em perspectiva pelo autor, em sua posição marginal na cultural nacional. Na confluência dessas perspectivas, delinea-se um elemento central na ficcionalizaçãopynchoniana da história moderna: a transição do sistema-mundo ocorrida no período de escrita da sua obra mais célebre.
\end{abstract}

Palavras-chave: $O$ arco-íris da gravidade; Thomas Pynchon; história americana; história moderna.

\begin{abstract}
:
Panoramic presentation of the fictionalization of American history in Thomas Pynchon's Gravity's rainbow. Three temporal references are used in the analysis: the period between 1620 and 1776, foundation of political and religious ideary that would determine the country's self-image; 1945 , moment of glorification of that self-image; 1973, year of publication of Pynchon's work. While the first two datings cover elements of the plot, the last one covers the time when the USA was being put into perspective by the author, in its marginal position in the national culture. At the confluence of these perspectives, a central element in the Pynchonian fictionalization of modern history is delineated: the transition of the worldsystem occurred during the period of writing of his most celebrated work.

Keywords: Gravity's rainbow; Thomas Pynchon; American history; Modern history.
\end{abstract}


Em seu giro pela história $O$ arco-íris da gravidade remetia insistentemente ao presente; em sua atmosfera de irrealidade, a obra tratava o passado com acuidade historiográfica. As vidas e as rotinas dos personagens se desenrolavam na história, gerando efeitos de superposição entre contingências individuais e o quadro amplo do sistema-mundo. Este artigo é a segunda parte de uma descrição panorâmica da visão da história na obra mais consagrada de Thomas Pynchon, tratando da sua ficcionalização da história moderna americana; um artigo anterior (também publicado na Eutomia)falou da modernidade europeia. Vamos direto ao assunto.

Em 1973, a publicaçãode uma obra como The logicof world power, de Franz Schurmann, indicava que tratar como imperialista a política externa americana podia soar polêmico (para a opinião pública interna), mas já se tornara plausível. Schurmann identificava, no governo americano, a intenção de construir "um dos experimentos mais radicais da história", intuído por Roosevelt ao final da Segunda Guerra e finalmente passível de execução a partir dos anos 6o: a unificação do mundo sob o comando dos EUA.Estivesse certa ou não, a noção gerava desconforto,contrastandofrontalmente coma autoimagem positiva do país desde 1945. Eo caso é que ainda hoje ela não costuma ser bem aceita internamente; há bem pouco tempo, uma resenha doNewYork Review of Books sobre o tema iniciava assim:

É difícil desistir de algo que você diz que nunca teve. Essa é a dificuldade dos americanos em relação ao império do seu país. Desde a época de Theodore Roosevelt, políticos, jornalistas e até mesmo alguns historiadores usam eufemismos [...] para disfarçar as ambições imperiais americanas.De acordo com o credo excepcionalista adotado tanto pelos partidos políticos quanto pela maioria da imprensa, o imperialismo foi um empreendimento europeu que envolvia capturar territórios, extrair seus recursos e dominar as suas populações (invariavelmente de pele escura). Os americanos, diz-se, fazem as coisas de maneira diferente: eles concedem autodeterminação a povos atrasados que anseiam por isso.(LEARS, 2019, tradução minha)

Essa visão benevolente nunca foi unânime, é claro; Mark Twain dela riria sem titubear. Mais tarde, abalada com a Guerra do Vietnã, no período de escrita de $O$ arco-íris da gravidade aquelacrença na missão de defesa global dos valores fundadores dos EUA - liberdade, democracia, justiça... - parecia impor aos americanos a escolha entre o"patriotismo monárquico" e o "patriotismo republicano", nos termos formulados por Mark Twaindurante a 
invasão das Filipinas, no final do século XIX: diante de um plano de exploração econômica justificado como defesa da democracia, Twain identificara o apoio incondicional prestado ao governo pelo "patriotamonárquico", tipo de ufanista que aceitavaacriticamente as ações do Estado, em contraste com o ceticismo do "patriota republicano", que se dava a liberdade de criticar o governo instituído em nome de um governo ideal, moralmente íntegro (cf. TWAIN, 2003, p.95-4).Na época de Pynchon, um bom exemplo de"patriotismo republicano" seria o documentário Corações e Mentes(1974), de Peter Davis, uma dura crítica,feita em nome de valores americanos,à presença americanano Vietna. Esse é um ponto a se ter em mente: a crítica aos EUA em nome de valores americanos - de novo: liberdade, democracia, justiça... -, eis a tônica também em $O$ arco-íris da gravidade.

O Vietnã aparece na obra de várias maneiras. Shawn Smith chega a propor que a narrativa é o esforço "do seu narrador de traçar paralelos e estabelecer uma linha de continuidade entre a Segunda Guerra Mundial e a Guerra do Vietnã" (SMITH, 2005, p.6o, trad. minha)- talvez uma essencialização excessiva do narrador, que não me parece ter uma única voz e intenção ao longo da narração. Seja como for, para produzirmos uma aproximação vívida da perturbação em cursoda autoimagem americanaé instrutivo voltar ao ambiente conflitivo dos anos 6o; farei-oinicialmente pela comparação entre algumas assertivas deThomas Paine eThomas Jefferson no quadro revolucionário do século XVIII, e,tanto tempo depois, a avaliação deLyndon Johnson da intervenção no Vietnã.

Em seu manifesto revolucionário, Paine proclamara que "A causa da América é, em grande parte, a causa de toda a humanidade" (PAINE, 1973, p.49). Os EUA teriam "toda oportunidade e todo encorajamento perante nós para formar a Constituição mais nobre e pura da face da terra. Podemos recomeçar o mundo. Nunca se verificou uma situação semelhante desde os tempos de Noé." (PAINE, 1973, p.88)O país seriao recomeço de uma história europeia universalizada como história global, visão ecoada por um confiante Thomas Jefferson: "enquanto estamos assegurando os direitos de nós mesmos e de nossa posteridade, estamos apontando o caminho para as nações em luta que desejam, como nós, emergir também de suas tiranias." (JEFFERSON, 1973, p.29)Ou seja, já o pensamento fundador do país articulava o universalismo político que eventualmente permearia a defesa, em momentos pontuais, da extensão por todo o globodas suas ideações e inovações institucionais: a democracia Eutomia, Recife, 23(1): 330-352, Jul. 2019 
representativa, o republicanismo, o sistema de freios e contrapesos entre os três poderes, os direitos individuais à felicidade, à liberdade de crença, à autodeterminação e à associação coletiva. Decerto auniversalização desses valores nem sempre estimulou políticas intervencionistas; pelo contrário, o isolacionismo foi sempre forte na opinião pública interna, particularmenteentre as guerras mundiais. Mas sob a justificação da Guerra Fria, e com a força da economia amparando as forças armadas, o apelo aos valores fundadores fundamentaria a retomada da missãoamericana pela liberdade e pela justiça como argumento em defesa da sua ação geopolítica. Para compreendermos o componente de autoengano implicado nessa racionalização, sugiro levarmos a sério, como uma demonstração generosa e otimista de fidelidade aos valores americanos, estadeclaração de LyndonJonhsonnuma retrospectiva da sua gestão da Guerra no Vietnã:

[V]ocê tem razão que a guerra é devastadora. Mas nós estávamos fazendo todo o possível para limitá-lo. Nós reconstruímos na medida em que prosseguíamos. [...] Hospitais, escolas, tecnologia. Nós queríamos modernizar a sociedade vietnamita. [...] A promessa da América sempre foi a da libertação dos limites estreitos. A fronteira. $O$ futuro. [...] Claro, os vietnamitas nunca mais serão os mesmos, mas eles tiveram todo um novo mundo aberto para eles. Mais escolhas. Libertação da superstição. A escolha de vidas alternativas. [...] Nós vamoscolocar essas coisas lá. Assim que este conflito estiver pacificamente encerrado. A América vai fazê-lo. Você vai ver. Nós temos, em nossa história, uma tradição de benevolência. Ela se mostrará lá também. (KEARNS, 1998, p.179-80, trad. minha)

Quem se deixava convencer por esse discurso no começo dos anos 70? Adesumanidade da Guerra do Vietnãdiluiraa percepção da diferença entre o internacionalismo americano e o fascismo europeu: a aproximação era exagerada, mas foi feita por muita gente - muitos americanos-, inclusive em $O$ arco-íris da gravidade. Era uma dramatização provocada pela oposição radical à guerra, que repudiava aautoimagem heroica dos EUA desde1945 enquanto criticava a covardia, barbárie e gratuidade do conflito atual. Para marcar o contraste entre 1945 e 1973, vejamos essas duas reportagens de guerra: um texto da Life Magazineque acompanha a foto de três marines mortos numa praia do Pacífico em 1943, e, mais abaixo, depoimentos de doissoldados que participaram do massacre de MyLai em 1968.

Da imagem dos corpos dos marines, os editores da Life proclamavam que

aqui na praia está a América, [...] três fragmentos daquela vida que chamamos de vida americana: três unidades de liberdade.Não foram apenas esses garotos que tombaram aqui, foi a liberdade que tombou. [...]A América é o

Eutomia, Recife, 23(1): 330-352, Jul. 2019 
símbolo da liberdade em toda a Terra. [...]E isso significa que, quando a liberdade tomba, como aconteceu aqui na praia de Buna, é nossa tarefa fazêla erguer-se novamente. (STROCK, 1995, p.642-3, trad. minha)

Implicitamente, o texto indicaque certos mitos de 1776não haviam sofrido grande abalo atéos anos 40. Prosseguia a idealização da terra americana, que "a Providência dotou", segundo John Jay em 1787, "com predileção particular, de prodigiosa variedade de terrenos e produções; deu-lhe rios inumeráveis para prazer e utilidade de seus habitantes." (JAY, 1973, p.96) Em 1943 areiteração dessa pureza pressunhaesquecer o massacre da população nativa, a escravidão e segregação racial,a tomada de metade do território mexicano no século XIX, a expansão sobre Cuba, Porto Rico e as Filipinas... Mas a reinterpretação da história americana baseada no resgate do seu passado imperialista seria motivada pelas convulsões dos anos 60; sobre o pano de fundo daquela autoidealização, compreende-se o impacto dos depoimentos deMichael Bernhardt e (logo abaixo) Michael Terry sobre MyLai:

"A coisa toda foi tão deliberada. Foi assinato a sangue frio e eu estava lá assistindo aquilo. [...] Eu caminhei e vi aqueles caras fazendo coisas estranhas. Eles faziam de três maneiras. Um: eles botavam fogo nas barracas e cabanas e esperavam as pessoas saírem e então atiravam nelas. Dois: eles entravam nas cabanas e atiravam nelas. Três: eles reuniam as pessoas em grupos e atiravam nelas. Enquanto eu caminhava, eu via gente empilhada pela aldeia afora." (HERSH, 1998, p.18, trad. minha)

"Eles os colocaram de pé sobre uma vala - coisa de nazista. [...] Um oficial ordenou que um menino metralhasse todo mundo, mas o menino não conseguia fazer aquilo. Ele jogou a metralhadora no chão e o oficial a pegou. [...] Um monte de gente acha que eles (os civis vietnamitas) não são seres humanos; a gente os tratava como animais." (HERSH, 1998, p.21, trad. minha)

No relato sobre MyLai a comparação com o nazismo não vinha de um opositor da guerra, mas de um militar presente ao massacre; a analogia tentava traduzir uma experiência vivida.Pynchona absorveria ao caracterizar os EUA, novo centro do sistema-mundo, como um Estado totalitário, incorporando esta leitura recente da sua política externa ao criticar o país contemporâneo:elos entre a Alemanha de Hitler e os EUA atuais perpassam a narrativa, que termina por volta de 1970 com a queda, sobre um teatro de Los Angelescujo proprietário era uma sátira de Richard Nixon, de umfoguete V-2 lançado na Europa em 1945.Os EUA haviam herdado um mundo pós-europeu, mas como eles geriam esse mundo e como se autogeriam ao geri-lo? A imagem de totalitarismo emerge do espelhamento entre um militarismo genocida Eutomia, Recife, 23(1): 330-352, Jul. 2019 
longe de casa,e a administração das consciências e modos de vida no cenário doméstico antecipando a associação chomskianaentre a agressividade no exteriore a "lavagem cerebral" interna:

Em $O$ arco-íris da gravidade,Pynchondá eco a uma crítica contracultural, cada vez mais freqüente, à repressão doEstablishmentem casa e ao seu imperialismo assassino no exterior. A obra revela a tradição pragmática do idealismo como uma "estrutura da morte" europeia, identificada com o imperialismo nazista e a "sociedade planejada" - uma formulação que Pynchon claramente conecta à retórica da América da Guerra Fria e à economia de guerra da era do Vietnã. (BAKER, 2003, p.99, trad. minha)

Essa comparação com o totalitarismo aparecia, por exemplo, na declaraçãodo alemão Weissmann, queexpunha a Gottfrieda sua interpretação mítica da história contemporânea:

"Na África, na Ásia, na Ameríndia, na Oceania, a Europa veio e instaurou sua ordem de Análise e Morte. O que não Ihe servia para nada ela matou ou alterou. Com o tempo, as colônias da morte tornaram-se fortes o bastante para desprender-se. Porém o impulso imperial, a missão de propagar a morte, a estrutura, permaneceu. Agora estamos na última fase. A Morte Americana veio para ocupar a Europa. Ela aprendeu as táticas de império com sua antiga metrópole. Mas agora só nos resta a estrutura, nenhuma das grandes plumas multicoloridas, nenhum detalhe em ouro, nenhum desfile épico sobre mares alcalinos. Os selvagens de outros continentes, corrompidos porém ainda resistindo em nome da vida, prosseguem apesar de tudo... enquanto a Morte e a Europa estão mais separadas do que nunca, seu amor ainda não foi consumado. A Morte apenas reina aqui. Ela jamais, por amor, fundiu-se..." (PYNCHON, 1998, p. 746).

Neste ponto a frase se interrompe: a Morte tomou a dianteira, passou aodomínio e ao comandohierárquico, e nunca "se fundiu" com a Europa, há tempos inferiorizada numa relação desigual. A estrutura do mito está montada: a origem do presente é localizada num passado remoto, porém conhecido, em que se dera o desequilíbrio trágico e a formulação dos termos pelos quais a redençãopoderia acontecer. No presente, a promessa da redenção é comprometida por forças que prolongam, de maneira sempre renovada, o desequilíbrio ancestral; por fim, tem-se uma atualização dapromessa de redenção, cuja efetivação, no entanto, permanece improvável. No mito de Weissmann os três momentos correspondem 1) à origem e desenvolvimento, no colonialismo, da Morte europeia, com quem a Europa deveria se unir numa plenitude que, no entanto, nunca chegara a ocorrer, pois os europeus desenvolveram a "matéria" da Morte ao disseminarem-napelo genocídio, mas nunca 
ascenderam ao Seu "espírito", e assima Europa permaneceu apartada da Morteao não transcender-se a si mesma e incorporar-se Nela; 2) se no colonialismo oitocentista a Morte ainda estivera revestida de um glamour aventureiro, no presente o que resta é a Sua estrutura material, mera sombra da plenitude prometida que, despida da metafísica original, fora facilmente apropriada pelos antigos aprendizes, os americanos, que agora sabem como aplicála, mas não compreendemo seu "espírito"; 3) ao final viriaa "Terra Prometida" de Weissmann, a concretização da união perfeita:"por amor", ele se fundiria com a Morte.

A rigor essa última parte não seria concretizada por ele mesmo, mas pelo sacrifício ritual de Gottfried, seu pupilo, que morreria para promover o matrimônio entre WeissmannEuropa e a Morte, Sua eterna prometida. As duas primeiras partes do mito podem ser lidas como remissão ao momento em que o centro do império passara da Europa aos EUA: haviam desaparecido o heroísmo da aventura, a sedução do exotismo, a "nobreza da tarefa civilizatória", e restaraa máquina genocida; sumiram o oitocentos de Kipling e do Dr. Livingstone, sobrou o de Conrad. Sob a ação americana,aMorte, originalmente europeia, se disseminaraainda mais e, se alguma contra-forçaainda subsistia, ela estava nas colônias, que "tornaram-se fortes o bastante para desprender-se", mas apenas para "resisti[r] em nome da vida, prossegu[ir] apesar de tudo..." Pouca esperança lhes parecia restar, portanto:haviapouca esperança para o Terceiro Mundo emsuas guerras fraticidas nos anos 60 e 70 . A remissão áspera ao sistema-mundo em 1973 radicavahistoricamente, pois, o discurso de Weissmann: o otimismo dos anos 50 fora rompido pelo tumulto social nas sociedades avançadas e pelos golpes e guerras no Terceiro Mundo, e "a crise tornou-se oficial e estrutural. O sistema de equilíbrios políticos e econômicos inventado em Bretton Woods mergulhara na mais completa desordem, e o que restou foi apenas o fato nu e cru da hegemonia dos EUA." (HARDT e NEGRI, 2003, p.287)

Note-se queHardt e Negri situam o império americano como epifenômeno do domínio da política pela economia, enquanto um Niall Ferguson - em Colosso, publicado pouco depois o vê como um fenômeno primordialmente político: em $O$ arco-íris da gravidadeele é uma e outra coisa, "capitalismo" ou "nação", a depender do contexto - ou ao mesmo tempo. Ferguson está entre aqueles que indicam que aconvicção no valor moral elevado da ação americana seria uma longa constante cultural a sustentar aação imperialista, implicada como Eutomia, Recife, 23(1): 330-352, Jul. 2019 
possibilidade já nesta declaração de Thomas Jefferson em 1798: "Realmente não desejo ver qualquer nação ter uma forma de governo forçada sobre ela, mas, se é que isso tem que ser feito, rejubilar-me-ia de ela ser a de um governo mais livre" (JEFFERSON, 1973, p.35); vinte e quatro anos mais tarde, ele escreveria a James Monroe: "Embora não tenhamos direito de interferir na forma de governo de outras nações, é, entretanto, lícito não desejarmos ver nenhum imperador ou rei em nosso hemisfério." (JEFFERSON, 1973, p.34) Já nos ideais fundadoresdo país identifica-seelementos da rationaleque justificaria as ambições imperiais do país, que se iniciaria com a ocupação dos territórios adjacentesàs treze colônias, seguida da aquisição territorial pela compra ou pela guerra (Flórida, Louisiana, as porções do Oeste tiradas do México, o Alasca, o Havaí...), desembocando, no século XX, nasintervenções em lugares distantes em defesa de interesses econômicos e geopolíticos.As ações mudaram com o tempo, mas já na fundação do país o recurso a nobres ideais oferecia a rationalepara intervenções daquele tipo:para Jefferson a liberdade eratão valiosaa ponto de justificar que ela fosse imposta a quem não conseguisse obtê-la pelos próprios meios - a imposição da liberdade perdia a condição de oxímoro.

Bem mais tarde, em 1973, esseoxímoroera plenamente identificável como pretexto para a consecução de outro tipo de interesse. Duzentos anos antes, quando Paine declarava, a respeito da construção de uma armada nacional americana, que uma vez "terminada [ela valeria] mais do que custou, e constitui o ponto interessante em que se unem, na política nacional, o comércio e a proteção" (PAINE, 1973, p.75), ele ainda a pensava como instrumento de defesa. Mas chegaria o dia em que ela se tornaria instrumento de ataque, cuja utilização seria estimulada pelo editorial do New York Times que - comportando-se como conselheiro do Estado, como Paine -,defendia assim, em fevereiro de 1950, a intervenção na Indochina francesa: "A Indochina é um prêmio que merece uma grande jogada. Ao Norte há estanho de exportação, tungstênio, manganês, carvão, madeiras e arroz; borracha, chá, pimenta e couros. Mesmo antes da Segunda Guerra Mundial a Indochina rendia dividendos calculados em 300 milhões de dólares por ano." (RUSSELL, 1968, p.148) Bertrand Russell identificaria esse editorial como parte integrante da política externa da Casa Branca, denunciando a aparente aceitação,pelo seu leitor, de justificações desse tipo para ações daquele gênero. 
Se o público absorvia que interesses econômicos fossem acobertados sob uma retórica universalista do Bem, nisso Russel identificava a cegueria do americano médio como um fenômeno cultural extenso; da perspectiva de Pynchon, essa cegueira seria explicada pela felidadeao ethospuritano. Este é o outro eixo de tematização da história americana no enredo, remetendo ao componente puritanosubjacente ao ideário fundador do país: nesses termos as convulsões implicadas entre 1945 e 1973 revolviam não apenas a longa duração inaugurada em 1776, mas também aquela inaugurada em 1620 com a chegada dos primeiros colonos à Nova Inglaterra. Tomado como constante cultural americana, em suas implicações políticas o puritanismo é tematizado pela vocação universalista para o Bem frequentemente alegada, nos EUA, como justificação para a sua ação externa:ao final, a produção do Mal nascia da convicção puritana de que o Bem estava implicado na ação americana como tal, e "talvez jamais haja existido forma mais intensa de valorização religiosa da ação moral do que aquela produzida pelo calvinismo em seus adeptos" (WEBER, 2004, p.105);"entre as variações do monoteísmo cristão, nenhuma é mais totalitária, nenhuma abriga um maior clamor pela onipotência de Deus que o [...] Puritanismo [Calvinista]." (SANDERS, 1976, p.139, trad. minha)

Na narrativa de Pynchon a reificação do ethospuritano tem sua origem demarcada em 1620, tomado como ponto germinal de crenças cuja naturalização determinaria, nos EUA de 1973, padrões corriqueiros de comportamento e expectativa. William Slothropfora o primeiro ancestral de Tyrone, um dos protagonistas centrais do enredo, a chegar à América em 1630 como cozinheiro da Arbella, "nau capitânia de uma grande frota puritana daquele ano." (PYNCHON, 1998, p.214) Williamé a ponte que liga o ethos calvinista original aos EUA contemporâneo,movimento pelo qual Pynchontirava o puritanismo do silêncio das práticas sociais para reinaugurá-lo como problema. No decurso da leitura ficamos sabendo que a família Slothrop não fora bem-sucedida financeiramente, e por isso ospais de Tyroneo venderam como cobaia de um experimento em troca de uma futura vaga em Harvard, abrindo-lhe umarota de ascensão social. Masseu ancestral William, livre-pensador,recusava essa resignação à assimilação. Isolado nas montanhas a oeste de Boston, ele

escreveu um longo panfleto [...] intitulado Da preterição. Só pôde publicá-lo na Inglaterra, e foi um dos primeiros livros que foram não apenas proibidos como também cerimoniosamente queimados em Boston. Ninguém queria ouvir falar de todos aqueles Preteridos, os muitos que Deus deixa de lado quando

Eutomia, Recife, 23(1): 330-352, Jul. 2019 
escolhe uns poucos para salvar. William defendia a santidade desses "segundos Cordeiros" sem os quais não haveria eleitos. [...] Segundo William, o que Jesus era para os Eleitos, Judas Iscariotes era para os Preteridos. Tudo na Criação tem sua contraparte igual e oposta. Como poderia Jesus ser uma exceção? Como poderíamos sentir por ele outra coisa que não o horror que inspira o antinatural, o extracriacional? Pois bem, se ele é o filho do homem, e se o que sentimos não é horror e sim amor, então temos que amar Judas também. Certo? Como William conseguiu não ser queimado por heresia, ninguém sabe. (PYNCHON, 1998, p.572-3)

William descrevia assim a apercepção de Jesus caminhando pelo mar da Galileia, que então teria entendido que "Sem os milhões que afundaram e se afogaram, não seria possivel haver nenhum milagre. O único que conseguiu foi apenas o outro lado da coisa: a última peça do quebra-cabeça, cuja forma já havia sido criada pelos Preteridos, como o último espaço vazio na mesa." (PYNCHON, 2017, p.533) William, que circulava pela América profunda, em meio aos seus preteridos, pensava como o Brecht de "Perguntas de um trabalhador que lê": uma massa de gente invisível, jamais reconhecida, produzia a história que é oficialmente narrada como a sucessão de feitos dos "grandes homens":

O jovem Alexandre conquistou a Índia.

Sozinho?

César bateu os gauleses.

Não levava sequer um cozinheiro? (BRECHT, 2001, p.166)

Com isso William se opunha a uma autoridade próxima.O fundadore primeiro governadorde Massachusettsera o famoso John Winthrop(vale notar a brincadeira por detrás do sobrenome Slothrop, que troca o win(vitória) do sobrenome do fundador da província pela sloth(preguiça) evocativa da preterição do personagem e sua família). Winthrop foi um dos idealizadores iniciais da América como um corpo político contratualista, mesmo que ele não fosse um democrata, não acreditasse na igualdade dos homens e defendesse um governo constitucional, porém concebido como uma república aristocrática da virtude (BEITZINGER, 1972, p.46). Ele escreveria "Um modelo de caridade cristã", texto central para a construção da autoimagem americana: tal como os filhos de Israel fizeram um pacto com Deus para preservar Seus mandamentos, obedecer Suas regras e seguir o caminho do bem, e tal como aquele pacto, e nada além dele, fizera dos judeus uma nação, os mesmo ocorreria com os puritanos da Massachusetts BayCompany.Ao comentar as consequências dessa ambição, Greil Marcus 
(2006) comenta que tal como, em Israel, trair o pacto era trair Deus, ao se assumirem como o povo de Deus na América - e assim fundando o excepcionalismo americano - os puritanos recriavam aquela ideia de nação como emissáriae modelo do bem, numa mensagem anunciada ao mundo e integrada à identidade americana. Mas essa ambição tanto evocavaum senso de importância, quanto a possibilidade do fracasso: daía compulsão dos americanos a julgar o país; daí a urgência, em especial, do herói ficcional americano em julgar a nação. O pacto que o passado firmou com o futuro da nação, e que segue atrelando o seu presente ao seu passado e ao seu futuro, fundaria a noção de que qual julgar o sucesso do país em sua fidelidade aos próprios ideais define, nos EUA, a própria cidadania: ser cidadão é ter o direito e a obrigação de julgar o país.

Marcus comenta que a memória do pacto fundador era parte do discurso público dedicado a definir a nação e o que ela representa, mas com o tempo se tornou críptica a ponto de, hoje, persistir mais na arte do que na política: é a arte que mais pergunta sobre o preço a ser pago quando o pacto é quebrado, ou sobre o preço já pago quando ele foi quebrado nalgum momento passado.Nação inventada, os EUA são julgados pelos seus símbolos, poiso país é uma construção, uma ideia que pode ser desfeita: a América existe em seus símbolos, e se eles forem destruídos a ideia será exposta como nada mais que uma ideia. Mas os pactos originais que mantêm o país unido, seguidos da liberdade de crença e expressão, e do direitoà felicidade e à justiça implicados na Declaração da Independência e na Constituição,essas promessas eram tão grandiosas que a sua traição se tornaria inevitável - ela se tornariam afinal, o drama nacional, o motor da história americana. Logo no momento em que os documentos foram promulgadosjá se podia ver que as promessas não eram cumpridas, motivando as sucessivas batalhas sobre a abolição da escravidão, o direito ao voto, à propriedade e à expressão... E tal como era inevitável que as promessas fossem traídas, era esperado que a América produzisse figuras proféticas, que criticariam aquelas ideações ou/e nelas se embasassem para criticar o país real - como tantos dos seus escritores.

Uma América que deve se autojulgar, que só pode se descrever se autojulgando, que vive (e goza) na instabilidade de ser fruto de uma ideia, e se refaz continuamente na tensão entre as suas promessas e as suas traições, sob a suspeita de que algum dia o equilíbrio se rompa - um país que teve um começo, que trazia em si a ideia de começo, a isso se combinava, Eutomia, Recife, 23(1): 330-352, Jul. 2019 
na Massachusetts de William Slothrop, um elemento lapidar do puritanismo: "Uma vez estabelecido que Seus decretos são imutáveis, a graça de Deus é tão imperdível por aqueles a quem foi concedida como inacessível àqueles a quem foi recusada." (WEBER, 2004, 95)Boa parte dos personagens de $O$ arco-íris da gravidadesão"preteridos",em contraposição aos "eleitos" do sistema, mas a lógica de William desestruturava por dentro o modelo: se também os preteridos deviam ser amados (como contraparte "dialética" do atributo da "eleição"), o amor puritano deveria se estender, indistintamente, a toda a humanidade - como o catolicismo, talvez, antípoda do cristão reformista? Ese o país poreleadotado se definiria como instrumento para a promoção universal do Bem, o narrador se perguntava em 1973:

Teria sido William o caminho que a América não escolheu na encruzilhada, o ponto exato em que o país pulou para o lado errado? E se a heresia slothropiana tivesse tido tempo de se consolidar e prosperar? Quem sabe não teria havido menos crimes em nome de Jesus e mais piedade em nome de Judas Iscariotes? (PYNCHON, 1998, p.573)

Aqui se fecha o loop. Os EUA eram a terra da democracia, mas como seria democrático um credo religioso que dividia a humanidade entre preteridoseeleitos? Não seria a noção essencialmente aristocrática? Mas o caso é que na época em que Pynchon escrevia $O$ arco-íris da gravidadeo puritanismo se encontrava numa crise imprevista, motivada pela perda de força normativa da sua ética do trabalho. Ascese individual, dedicação ao trabalho como missão intramundana, "Por duzentos anos [...] os americanos haviam acreditado na abnegaçãoe na ética protestante. Agora estas 'velhas regras'estavam sendo postas de lado, sendo substituídas por 'novas regras' de autosatisfação, de gratificação imediata e liberdade pessoal." (CHAFE, 1999, p.430, trad. minha) O individualismo mitigava o puritanismo como fundamento dos modos e objetivos pessoais de vida, assim como do conceito-de-si e da imaginação políticaamericana; de maneira genérica, começava a entrar em crise a confiança nos ideais fundadores, que passavam a revelar seu componente mítico:

Durante a maior parte da sua história, oa americanos [...] desposaram o "credo americano" - liberdade individual, igualdade de proteção perante a lei, oportunidade de avanço com base no mérito e a capacidade, pela parte de baixo da sociedade, de assugurar a melhoria do seu quinhão através do trabalho duro e da participação nos processos políticos estabelecidos. [...] a influência [desse credo] na alma e na mente da América era tal que mesmo aqueles com os melhores motivos para desagrado conduziam suas lutas pela liberdade dentro dos seus dispositivos, convencidos, nas palavras de Martin 
Luther King, Jr., que "algum dia, algum dia" o sonho da dignidade e da justiça para todos se tornaria realidade. (CHAFE, 1999, p.341, trad. minha)

Na esteira da crítica radical à guerra do Vietnã e do crescimento da violência racial no país, tambémO arco-íris da gravidadecriticaria aquele "credo". Mas se a obra caracterizava um povo alienado do sistema, ignorante sobre o jogo de poder e impotente politicamente, quem, no enredo, estaria apto a identificar a existência daquele hábito mental? TyroneSlothrop estava fora do país, e isso o ajudaria um tanto; segundo um comentarista, "A partir de Hawthorne, o escritor americano parece freqüentemente sentir ou implicar: 'eu sou um cidadão de outro lugar'." (TANNER, 1971, p.21, trad. minha) Isso soa familiar: o intelectual como um "estrangeiro em sua própria terra"... Seja a proposição generalizável ou não, Pynchonnela se encaixa, analisando seu país com olhar de estrangeiro. Mas isso geravauma dialética tensa, sem telosà vista.Em parte o "senso comum" americano está reduzido à cegueira, externo às grandes engrenagens e incapaz de entender seu próprio mundo, chegando a ser inocentado, em $O$ arco-íris da gravidade, pela sua ignorância e impotência - se a radicação da ignorância vinha de 1620,ele não podia ser responsabilizado por uma cegueira que já se tornava "segunda natureza".É preciso, então, estar fora do "senso comum" para bem descrevê-lo, masPynchon, com seu olhar de estrangeiro, não se punhaintegralmente fora da mediania que ele observava à distância: não é tão simples assim.

Ele não rejeita e nem elogia o "americano comum", com quem ele tampouco poderiase identificar:a relação é ambígua e não há nela qualquer dicotomia clara, ética, moral e politicamentevalorada, como aquelas dramatizadas, no enredo, entre mocovitase quirguizes, porteños e gauchos - em que cada um aparece, perante o outro, como franca alteridade. $\mathrm{O}$ narrador não rompe com a mediania,nem seintegra a ela: onde situá-lo? Ele é heterogêneo à mediania, quefigura no "panodefundo": referências ao quadro sócio-histórico em que o americano médio é protagonista vêm como fragmentos ejetados no contínuo narrativo, sem antecipação ouconexão com o enredo, esalpicados em longos intervalos, compouca ou nenhuma relevância para a diegese. A maioria dessas remissões ao país vem de um narrador que radicaliza, nesses instantes, a sua posição heterodiegética, intrometendo narrações intercaladas ou digressões sobre lugares, noções, imagens, personagens e símbolos americanos que apenas lentamente constituem conjunto ao longo danarrativa. É assim que, Eutomia, Recife, 23(1): 330-352, Jul. 2019 
tendo Slothroprecebido de Waxwing um zootsuit, a narrativa pula para oszootsuitriotsde 1943, quando militares e civisatacaram violentamente, em Los Angeles, centenas de jovens de origem mexicana, inicialmente escolhendo como alvo os que vestiam aquele tipo de terno; ao sair do enredo para remeter ao fato histórico, a narração sugere que os motivos contextuais da agressão eram menos importantes do que a expressão de racismo,recorrente na sociedade americana. De maneira semelhante, uma passagem sobre a obediência dos Slothropà ética de trabalho protestante ("trabalhavam em silêncio, assimilados em vida à dinâmica que os cercava por completo, tal como na morte os cercaria a terra dos cemitérios" (PYNCHON, 2017, p.33) termina nesta generalização: "Merda, dinheiro e o Verbo, as três verdades americanas, combustíveis da moralidade americana, atrelavam os Slothrop para todo o sempre ao destino da nação" (PYNCHON, 2017, p.33).

Em meio a essas aparições abruptas da América no enredo, Pynchonpreservacerta simpatia pela autenticidade e honestidade do americano "preterido", mesmo ao criticar a alienação implicada em seu desejo de ascensão social. É um modo convencional de compreensão da classe média local, que não a rejeita ostensivamente: seasua ignorância sustenta um sistema corrupto, ela também explica a ingenuidade dos seus pequenos hábitos e ambições; há condescendência nesse olhar, mas sem rejeição pura e simples. Nalgum nível Pychonpensaos EUA democraticamente, interpretando a medianiaem seus próprios termos; mesmo que,estrangeiro em sua própria terra, ele tenda a homogeneizar o que the parece diferente, ele não disseca a massapara decretar a sua insuficiência ou idealizá-la positivamente: é uma voz que pertence àsociedade que observa à distância, aporética eagonisticamente.

Dessa perspectiva, parte dos problemas do senso comum americano pode ser atribuída à insularidade do país, ao autocentramento de uma população cercada por dois oceanos num território continental, imersa em si mesma e seus assuntos internos (o Brasil não é muito diferente).No presente da narração (em 1945), tradicionalmente o americano tinha pouco contato com o exterior e, então como ainda hoje, com as consequências das ações do seu país no exterior. É o que Bertrand Russell dirianum libelocontra a Guerra do Vietnã que, endereçado ao americano médio, terminava com um apelo que pressupunha a sua alienação quanto às 
conseqüências da política externa do país - algo que, ao se tratar da agressão de nações estrangeiras, se transformava em desvio moral:

Apelo para os americanos, que jamais souberam em sua vida o que é ter um exército estrangeiro ocupando seu território, e jamais sofreram a destruição sistemática de seu país pelo ar, para que tentem, com a imaginação, compreender o que está acontecendo no Vietnã. (RUSSELL, 1968, p.129)

Esseapelo não precisaria ser dirigido, naquela época, a um europeu adulto, que conheceria bem a realidade descrita.Num outro exemplo bem mais prosaico de incômodo com a insularidade americana, um jornalista americano que acabara de voltarda Europa em 1941 se encontra com um colega que também estivera por lá, e eles compartilhamsuas percepções sobre a miopia dos conterrâneos em relação ao conflito em que o seu país logo entraria: "Sair do avião e encontrar as pessoas que haviam permanecido na América era uma experiência estranha, porque eles pouco pareciam saber que alguma coisa estivesse errada" (LIEBLING, 1995, p.174, trad. minha); ao que o outro acrescenta: "'Eu não me sinto como um marciano, mas como um terráqueo que aterrisou noutro planeta. Estes tolos não sabem o que está acontecendo na Terra?"' (LIEBLING, 1995, p.177, trad. minha) Situações desse tipo pareciam pipocar continuamente: décadas mais tarde, durante a Guerra do Vietnã, ao tentar chamar a atenção da opinião pública localpara as atrocidades cometidas pelo seu exército naquele país distante, uma jornalista constatava que a guerra "acontece nalgum outro lugar, muito distante. Mais longe do que jamais antes, no Vietnã do Sul, uma guerra está sendo travada em nosso nome" (GELLHORN, 1998, p.287, trad. minha) - nessa mesma linha, mas com um sarcasmo que o jornalismo não permitiria, lemos esta passagem em $O$ arco-íris da gravidade:

Dungannon, Virgínia, ou Bristol, Tennessee, ou Asheville ou Franklin, Carolina do Norte, ou Apalachicola, Flórida, ou quem sabe Murdo Mackenzie, Dakota do Sul, ou Phillipsburg, Kansas, ou Stockton Palinville, ou Ellis, Kansas - é mesmo, parece uma Lista de Homenageados, não é?, sendo lida em algum lugar na pradaria, cores de fundição riscando o céu em longas calhas, vermelhas e roxas, multidão escura de civis eretos e quase se tocando, como talos de trigo, e um único velho de preto diante do microfone, lendo os nomes das cidades que perderam filhos na guerra, [...] os cantos das pálpebras descendo sérios cada vez que os nomes das cidades-mártires, um por um, ecoam na bigorna da planície. [...]

Pois bem, você está redondamente enganado, campeão - essas cidades são todas localizadas nas fronteiras da Fusos Horários, só isso. Há, há! Apanhei-te com a boca na botija. Vamos, agora mostre tudo que você estava fazendo ou então caia fora da área, não precisamos de gente da sua laia, não.

Eutomia, Recife, 23(1): 330-352, Jul. 2019 
Nada é mais asqueroso que um surrealista sentimental. (PYNCHON, 1998, p.718)

O narrador elenca cidades pequenas, tipo de lugarejo de onde sempre parecem viros mártires nacionais: a smalltownque, na literatura e no cinema, pontua a constância da "América profunda" em contraposição ao cosmopolitismo da cidade grande. Ocorre que a solenidade da perda dos heróis nos lugares listados por Pynchon em nada se assemelhava ao cotidiano das perdas nos lugares onde os EUA faziam a guerra: as mortes dos "filhos do solo" eram contabilizadas individualmente, enquanto as centenas de milhares de vietnamitas mortos produziam, para os americanos, um conjunto de estatísticas. E distribuídas pelos rincões de um território gigantesco, a morte heróicaproduzia sofrimento em lugares que nunca transformariam aquele sofrimento em pressão pela mudança - pior, na representação de Pynchoneles acreditavam no valor do sacrifício, cuja nobreza o narrador tratacom cinismo. São justamente as lágrimas daqueles que se enternecem com a dor patriótica que eleafrontaimediatamente após listar as supostas cidades-mártires, revelando que aquelas eramapenas cidades "localizadas nas fronteiras dosFusos Horários, só isso. Há, há!",e assim achincalhando a possível comoção pela morte patriótica. Por implicação, a distância geográfica entre o Vietnã e a Dakota do Sulera projetada como fator de sustentação dasações do Estado; como diria um historiador, "O peso muito menor imposto às potências ocidentais na derrota do facismo,além da completa exclusão da guerra do seu próprio território pelos EUA, permitiram que os seus líderes e as suas populações contemplassem a guerra [...] com muito mais descaso e irresponsabilidade." (HALLIDAY, 1986, p.40, trad. minha) A insularidade sustentava, portanto,a irresponsabilidade militar, um elo a conectar a bandeira patrioticamente hasteada no frontão da casa interiorana à devastação do Vietnã do Norte.

Mas à cidade pequena, símbolo da insularidade, não cabe apenas a função negativa de fundamentação da cegueira. Mingeborough, cidade natal de Slothrop, é objeto de singelas recordações da infância, como quando ele

Cochila e sonha com pássaros, uma densa revoada de emberizas-das-neves, um cair de folhas de pássaros, em meio à neve densa que desce. Slothrop está em Berkshire. É pequeno, e segura a mão do pai. O tapete de aves balança, impelido para cima, para o lado, pela tempestade, depois para baixo outra vez, à procura de comida. "Tadinhos", diz Slothrop, e sente o pai apertar-lhe a mão através da luva de lã. (PYNCHON, 1998, p.405-6)

Eutomia, Recife, 23(1): 330-352, Jul. 2019 
O lugar da infância, em sua pureza virginal, é também o lugar da primeira formação política:

Slothrop estava entrando no colegial quando FDR estava entrando na Casa Branca. [...] o jovem Tyrone achava-o corajoso, com a poliomelite e tudo. Gostava de sua voz no rádio. Quase o viu uma vez, em Pittsfield, mas Lloyd Nipple, o garoto mais gordo de Mingeborough, estava bem na sua frente, e Slothrop só conseguiu ver duas rodas e os pés de uns homens de terno num estribo de automóvel. [...] Roosevelt era o seu presidente, o único que ele jamais conhecera. Tinha-se e impressão de que ele seria eternamente reeleito, um mandato após o outro. (PYNCHON, 1998, p.387)

Mingeborough é, acima de tudo, um microcosmo imerso na sua própria pequena realidade, isolado do exterior, habituado a modos de vida que desejavam preservar-se eternamente.Como tanto acontece, Pynchon não estabiliza o significado do que ele mesmo produz: a palavra mingesignifica vulva; com isso em mente, a pouquíssimas páginas do final do livrohá um subcapítulo intitulado "A ocupação de Mingeborough". Os motivos da ocupação militar não são explicados, mas isso é irrelevante: o que importa é a exposição de uma paz cristalina, para sempre destruída quando chegam os ocupantes:

À beira da estrada há uma macieira em flor. Os galhos estão úmidos da chuva matinal, escuros e úmidos. Sentada à sombra da árvore, com ninguém menos que Slothrop, encontra-se uma moça loura, pele bronzeada cor de mel, as pernas de fora. O nome dela é Marjorie. Hogan vai voltar do Pacífico e tentar conquistá-la, mas vai perdê-la para Pete Dufay. Ela e Dufay terão uma filha chamada Kim, e o jovem Hogan Júnior vai enfiar as pontas das tranças de Kim nos tinteiros da escola. [...] Mas tem a ocupação. Talvez já tenham interditado os atalhos dos garotos junto com as rotas dos adultos. Talvez seja tarde demais para voltar para casa. (PYNCHON, 1998, p.768-9)

É o fim da insularidade? Fora Mingeborough finalmente deflorada? Seria, afinal, o fim da cegueira americana, numa metáfora da violência na sociedade civil nos anos 6o, abalando de dentro a sua propensão ao autodesconhecimento? Não temos como saber as intenções de Pynchon, mas é certo que aquela violência pôs fim à quietude de muitas Mingeboroughs país afora. Quando, em maio de 1970, a Guarda Nacional assassinou estudantes de Kent State que protestavam contra a Guerra do Vietnã, uma moradora da região reagiu assim, num jornal local, contra o testemunho de um estudante que criticava a ação da polícia: "Como eles ousam! Eu apóio a ação da Guarda Nacional! Eu quero a minha propriedade defendida. [...] Urra! Eu 
grito por Deus e pelo País, pelo recurso à justiça pela lei, flautas, tambores, música marcial, paradas, casquinhas de sorvete - América, ame-a ou deixe-a." (MICHENER, 1998, p.75, trad. minha)É sintomático que a leitora tenha feito, seriamente, associações semelhantes àquelas que $O$ arco-íris da gravidadeironiza: "Deus", "casquinhas de sorvete"...e "América".

Outro leitor do jornal, autoproclamando-se representante da "maioria sileciosa" (termo cunhado por Nixon para mobilizar a paixão pela ordem do eleitorado nacionalista), declararia que "A Guarda Nacional cometeu apenas um erro - eles deveriam ter atirado mais cedo e durante mais tempo." (MICHENER, 1998, p.79, trad. minha) Se é plausível sugerir que $O$ arcoíris da gravidade denunciavao desejo de segurança dos EUA-Mingeborough como uma recusa semiconsciente em confrontar a fratura da sociedade americana, contra o risco do patriotismo que - não raro ingenuamente - sustentava o statu quo,todo sentimentalismo deveria ser evitado, mesmo quando a causa era justa:na narrativa de Pynchon, as baixas americanas na guerra não são sofridas nem glorificadas; na passagem abaixo, há ironia na visão dos soldados mortos após a vitória dos Aliados nas Ardenas:

Por um momento, dez mil defuntos enterrados sob a neve em Ardennes assumem uma expressão disneyana de bebês numerados sob cobertores brancos de lã, aguardando a hora de ser enviados para pais abençoados em lugares como Newton Upper Falls. Isso dura só um instante. Depois, por um outro instante, é como se todos os sinos natalinos da Criação estivessem prestes a bater em uníssono - como se seu dobrar aleatório, por uma única vez, fosse coordenar-se, em harmonia, cheio de promessas de conforto explícito e júbilo praticável. (PYNCHON, 1998, p.77)

Se, no país, real, os soldados da Segunda Guerra foram glorificados - ao contrário dos veteranos do Vietnã -, em Pynchona participação americana no conflito não é dramatizada. $\mathrm{Na}$ Alemanha recém-libertada os recrutas se divertem, fazem festa, se drogam, praticam pequenascontravenções. Nos meses subseqüentes ao finaldo conflito a Europa não evoca, neles, qualquer senso histórico da própria missão que não fosse reprodução da propaganda oficial, e a sua frequente leviandade, tolice, superficialidade e indiferença faz de $O$ arco-íris $d a$ gravidadeuma contranarrativa da história oficial americana sobre a Segunda Guerra - o que é reforçado pela projeção do conflito como um episódio momentâneo na gestão de um sistemamundo que promoveriaa guerra à condição de necessidade operacional. Maio de 1945 não seria um marco, mas uma transição, e não surpreende que a única menção ao Dia da Vitória 
ocupe umas linhas rápidas, marcadas pelo distanciamento irônico: "Estamos de novo em tempos de paz agora, mal havia lugar para os pombos em Trafalgar Square na noite do Dia da Vitória, todo mundo no trabalho totalmente de porre, se abraçando e se beijando..." (PYNCHON, 1998, p.280-1) No dia seguinte, as rotinas são retomadas.

Nessa guerra definida como elemento de uma macroengrenagem que se autoalimenta, a contranarrativa de Pynchontambém atingia, em 1973, um elemento crucial da retórica política americana: a Guerra Fria. Para os EUA de Pynchon o oponente central não era a URSS, mas a violência dos preteridos:o Terceiro Mundo no exterior,os negros em casa. Ambos impunhamagressivamente o direito à autodeterminação, e a novidade desses embates, em 1973, começava a colocar a Guerra Fria - no período da détente- em segundo plano. A URSS aparece integrada ao sistema-mundo que incluía todo o planeta, antecipando o juízo retrospectivo de Wallerstein: "a Guerra Fria não era um jogo a ser vencido, mas um minueto a ser dançado." (WALLERSTEIN, 2000, p.400, trad. minha) ParaWallerstein, o embate com a URSS facilitou a influência americana sobre o mundo, ao permitir-lheconcentrar os seus investimentos na reconstrução da porção menor e mais rentável da Europa (deixando de fora o Leste Europeu), impulsionar a economia interna pelo investimento maciço na indústria bélica, e controlar as trocas econômicas entre as nações abrigadas sob a sua área de influência. Tudo ia bem até a rebelião dos "preteridos": "Juntamente com a prosperidade dos EUA e mesmo do mundo, veio a percepção do fosso crescente, internacionalmente e dentro dos Estados Unidos, entre os ricos e os pobres, entre o centro e a periferia, entre os incluídos e os excluídos." (WALLERSTEIN, 2000, p.394-5, trad. minha)

As forças liberadas pelas reivindicações dos excluídos desestabilizaria a política interna americana nos anos 6o. O racismoé um tema central em $O$ arco-íris da gravidade, e em 1973 a novidade na questão não era a sua presença no debate público, mas a sua promessa de violência. Vejamos este trecho de uma reportagem de 1969 sobre a conscientização racial do soldado negro no Vietnã:após um longo relato sobre o aumento da tensão entre militares brancos e negros, ela conclui com o prenúncio de uma guerra civil:

Diferentemente dos veteranos de um ano ou dois atrás, eles estão imersos na consciência negra e no orgulho racial. Será logo neste outono e inverno que eles estarão retornando à vida civil nas cidades. Se eles descobrirem que nada mudou por ali, eles poderão constituir uma força formidável nas ruas da 
América, formados eexperimentados em todas as artes violentas como nenhuma geração de negros jamais foi. (TERRY, 1998, p.708, trad. minha)

O jornalista imagina, de forma sombria, que um exército de negros poderia se insurgir contra o próprio país, sem deixar claro se a reportagem sugeria a necessidade de se antecipar à violência para evitá-la de alguma forma, ou se ela entendia que o conflito era irreversível (saber que Wallace Terry era um negro politicamente engajado não muda a ambiguidade; no máximo, explica o cuidado retórico da sua enunciação). Para a nossa discussão, importa destacar a semelhança entre os tons de presságio eameaça do seu texto e uma das primeiras menções ao contato entre brancos e negros em $O$ arco-íris da gravidade: logo na sequência em que Slothrop se lembra do clube de jazz em que ele perderia uma gaita na privada, o narrador, tomando-o como foco narrativo, destaca os "Rostos negros, toalhas de mesa brancas,facas afiadíssimas a reluzir alinhadas junto aos pires..." (PYNCHON, 2017, p.65, grifos do autor)A primeira imagem da negritude servil, que atendia a clientela branca em Boston, pula do contraste entre as cores negra e branca para a arma à mão para uso imediato - qual uso, exatamente? O engraxate no banheiro onde Slothrop perderia a gaita era Malcolm $X$, que entre o presente da narração e o presente da leituraescreveria Negros withguns, defendendo o armamento da comunidade negra como autodefesa: qual seria o usodaquelas facas, então?

Era essa a violência que surgia como novidade nos EUA dos anos 6o: não o conflito épico entre exércitos e potências para o triunfo final dos justos, mas a violência suja, carregada de ressentimento, que dissolvia a ilusão da "Boa Sociedade". Os fantasmas não estavam "lá fora", como a ideologização da Guerra Fria fizera crer. Eles estavam bem diante dos americanos, e não havia onde se esconder: qualquer solução envolveria diminuir o favorecimento dos "eleitos" ou aumentara violência contra os "preteridos". A ausência da promessa de solução prometia perenizar a violência, e da sua fundação moral em 1620 renovada em 1776 - à sua refundação em 1945, os EUA puritanos chegavam a um impasse em 1973. Hobsbawndiria que "A história dos vinte anos após 1973 é a de um mundo que perdeu suas referências e resvalou para a instabilidade e a crise." (HOBSBAWN, 1997, p.393) Que nova ordem viria daí? Em especial: que ordem política moralmente positiva poderiam os EUA construir dentro de uma crise sistêmica, das suas fraturas internas e diante da insurgência do Terceiro Mundo? Se a ordem europeia acabara para sempre, quais seriam, para o observador Eutomia, Recife, 23(1): 330-352, Jul. 2019 
de 1973, asfeições da ordem americana? Esmorecia a autoconfiança dos anos 50; em seu lugar, nada de sólido parecia emergir:

Por quase trinta anos após a Segunda Guerra Mundial, os americanos haviam controlado o seu destino econômico e dominado o mundo. Agora, aquela era parecia ter acabado. Um novo senso de limites se estabeleceu, com os americanos forçados a confrontar realidades em casa e no exterior que eram amedrontadoras. Contudo, se uma era havia encerrado, não estava claro, de maneira alguma, o que próxima iria trazer. Os anos 70 se tornaram, pois, uma década de transição - marcada pela confusão, pela frustração e pelo sentimento avassalador de que a América havia perdido seu rumo. (CHAFE, 1999, p.430, trad. minha)

Na falta de fundamento para o otimismo, Pynchon parecia imaginar o futuro do novo Império em sintonia com a profecia lançada por um jornalista em 1965: "A 'guerrinha suja' no Vietnã é um conflito bagunçado e confuso, mas é do tipo que os Estados Unidos poderão estar lutando por muitos anos à frente - se não na Ásia, então na África ou na América Latina?" (TUOHY, 1998, p.196, trad. minha) Impressões como essa pavimentaram o caminho para o discurso testamental de Weissmann: os EUA haviam aprendido "as táticas de império com sua antiga metrópole". Em $O$ arco-íris da gravidade, era assim que uma sombria Era Americana prometia prolongar-seindefinidamente no tempo.

\section{Referências bibliográficas}

BAKER, Jeffrey S. On the radical critique of American imperialism on the 1960s". In: BLOOM, H. (org.). Thomas Pynchon.1. ed.Broomall: Chelsea House, 2003, p. 97-102.

BEITZINGER, A. J. A History of American Political Thought. 1. ed.New York: Dodd, Mead \& Company, 1972.

BRECHT, Bertolt.Perguntas de um trabalhador que lê. In:Poemas 1913-1956. 1. ed.São Paulo: Ed.34, 2001.

CHAFE, William H. The unfinished journey. America since World War II. 1. ed.New York: Oxford University Press, 1999.

GELLHORN, Martha. Suffer the little children... . In: BATES, Milton J. et al. Reporting Vietnam: American Journalism 1959-1969. 1. ed.New York: The Library of America, 1998, p. 287-297. 
HALLIDAY, Fred. The making of the second cold war. 1. ed.London: Verso, 1986.

HARDT, Michael, e NEGRI, Antonio. Império. 1. ed. Rio de Janeiro: Record, 2003.

HERSH, Seymour M. The My Lai massacre. In: BATES, Milton J. et al. Reporting Vietnam: American Journalism 1959-1969. 1. ed.New York: The Library of America, 1998, p. 13-27.

HOBSBAWN, Eric J. Era dos extremos. O breve século XX, 1914-1991. 1. ed. São Paulo: Companhia das Letras, 1997

JAY, John,HAMILTON, Alexander e MADISON, James. O Federalista. In: WEFFORT, F. (org.). Os Pensadores XXIX - Jefferson, Paine, Federalistas, Tocqueville. 1. ed. São Paulo: Abril, 1973, p. 91-184.

JEFFERSON, Thomas. Escritos políticos. In: WEFFORT, F. (org.). Os Pensadores XXIX Jefferson, Paine, Federalistas, Tocqueville. 1. ed. São Paulo: Abril, 1973, p. 7-46.

KEARNS, Doris. LBJ remembers Vietnam. Inn: BATES, Milton J. et al. Reporting Vietnam: American Journalism 1959-1969. 1. ed.New York: The Library of America, 1998, p. 161-18o. LEARS, Jacskon. Imperial excepcionalism. In:The New York Review of Books, Volume 66, Number 2. Disponivelemhttps://www.nybooks.com/articles/2019/02/07/imperial-exceptionalism/. (acessado em 25/06/2019)

LIEBLING, A. J. "Remoteness from the war affected everybody". In: HYNES, Samuel et al. Reporting World War II: American Journalism 1938-1944. 1. ed.New York: The Library of America, 1995, p. 173-183.

MARCUS, Greil. The shape of things to come. Prophecy and the American voice. 1. ed.New York: Farrar, Straus and Giroux, 2006.

MICHENER, James A. Kent, Ohio: May 1970. In: BATES, Milton J. et al. Reporting Vietnam: American Journalism 1959-1969. 1. ed.New York: The Library of America, 1998, p. 57-84.

PAINE, Thomas. Sensocomum. In: WEFFORT, F. (org.). Os Pensadores XXIX - Jefferson, Paine, Federalistas, Tocqueville. 1. ed.São Paulo: Abril, 1973, p. 47-89.

PYNCHON, Thomas. O arco-íris da gravidade. 1. ed. São Paulo: Companhia das Letras, 1998.

PYNCHON, Thomas. O arco-íris da gravidade. 2. ed. São Paulo: Companhia das Letras, 2017.

RUSSELL, Bertrand. Crimes de guerra no Vietnã.1. ed. Rio de Janeiro: Civilização Brasileira, 1968. 
SANDERS, Scott. Pynchon's paranoid history. In: LEVINE, G., e LEVERENZ, D. (orgs.). Mindfulpleasures. Essayson Thomas Pynchon. 1. ed.Boston: Little, Brown and Company, 1976, p. 139-159.

SMITH, Shawn. Pynchon and History. Metahistorical rhetoric and postmodern narrative form in the novels of Thomas Pynchon. 1. ed.New York: Routledge, 2005.

STROCK, George/Life Magazine. Three Americans. In: HYNES, Samuel et al. Reporting World War II: American Journalism 1938-1944. 1. ed.New York: The Library of America, 1995, p. 639-643.

TANNER, Tony. City of words. American fiction 1950-1970. 1. ed.New York: Harper \& Row, 1971.

TERRY, Wallace. Black power in Viet Nam. In: BATES, Milton J. et al. Reporting Vietnam: American Journalism 1959-1969. 1. ed.New York: The Library of America, 1998, p. 704-708.

TUOHY, William. A big 'dirty little war'. In: BATES, Milton J. et al. Reporting Vietnam: American Journalism 1959-1969. 1. ed. New York: The Library of America, 1998, p. 187-197.

TWAIN, Mark. Patriotas e traidores. 1. ed. São Paulo: Editora Fundação Perseu Abramo, 2003. WALLERSTEIN, Immanuel. America and the world: today, yesterday, and tomorrow. In:The essential Wallerstein.1. ed. New York: The New Press, 2000, p. 387-415.

WEBER, Max. A ética protestante e o "espírito" do capitalismo. 1. ed. São Paulo: Companhia das Letras, 2004.

iPedro DOLABELA CHAGAS, prof. Dr. Universidade Federal do Paraná (UFPR) Departamento de Literatura e Linguística E-mail:dolabelachagas@gmail.com

RECEBIDO EM 06/05/2019

ACEITO EM 28/06/2019 